\title{
A STUDY OF EUROPEAN SPEECH
}

\section{DEFECTIVE SCHOOL CHILDREN IN PRETORIA}

\author{
L. WEISS, B.A. Log. M.A.
}

\section{THE SCOPE OF THIS STUDY:}

63 schools with a total school population of 33,482 children were studied. These excluded all special schюols and all schools not administered by the Transvaal Education Department. Among these children, 1,513 were found to have speech defects severe enough to enable teachers to diagnose the children as having "something" wrong with their speech. This figure represents 4.5 per cent. of the school population studied.

\section{FINDINGS}

1. Among the speech defective children studied 38 per cent. were Dyslalic, and 28 per cent. were Dysphemic.

2. The ratio among the sexes was on an average 2.2 boys to 1 girl increasing to 3 boys to one girl among the Dysphemics.

3. Some interesting differences were found in the incidence of speech defectives children in different types of schools. It was found that the largest incidence occurred in the Afrikaans Medium high schools, 5.2 per cent. while the lowest incidence of only 2.2 per cent. occurred in the English Medium high schools. The results though very interesting and giving us much food for thought, are not completely reliable, since surveys were in most instances done by school teachers, and since there are very few English Medium High schools in Pretoria.

The discrepancy in the primary schools was not as great, the Afrikaans school with 4.8 per cent. and the English schools again lower with 3.7 per cent.

Dual medium schools cannot be compared as only three schools were available for study, although it can be stated that the incidence of sprech defectives was higher than among any of the other types of schools.

4. It was also found that youngest children in the family had a significantly higher incidence of specch defects, than children in other positions.

IRESULTS OF THERAPY:

This included ionly a fow schools, where children were treated once or twice a wcek, for a period from 6 to 10 months. Response to therapy was on the whole very gratifying, 92 per cent. of the children showing definite improvement, including almost 50 pcr cent. who were completely rehabilitated in such a short time.

May I conclude by stating my firm belief that the Speech Defective school children must be hclped, and that we can help him to attain his rightful place in the community by helping him whilc he is still at school.

\section{RIDE

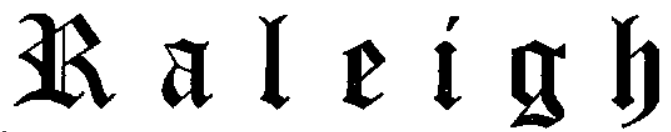

The Greatest Name in Cycling

ON TERMS 7s. 6d. WEEKLY FROM ALL RALEIGH CYCLE DEALERS 